\title{
PATENTS ON GENE SEQUENCES
}

Clarisse de la Cerda

\author{
The author holds a master's degree in intellectual property \\ law granted by the State University of Rio de Janeiro (UERJ) \\ and works with technology transfer agreements at a law firm \\ specialized in intellectual property. \\ cladelacerda@gmail.com
}

\begin{abstract}
The patents on gene sequences are a controversial theme in the setting of intellectual property. The discussion revolves around the supposed inventiveness of these genetic materials: would they be considered true inventions or mere discoveries? It is certain that there is no unanimity of treatment. This study sought to systematize the patentability on genetic materials, under the decision on the Myriad Case, decided by the U. S. Supreme Court. Also, an analysis of the Brazilian legislation was necessary, as well as an understanding of the Brazilian Patent Office's practice. Considerations were made regarding whether the protection of biotechnological inventions is necessary, pondering the mandatory social purpose of the scientific and technological development established by the Brazilian Constitution.
\end{abstract}

Keywords: Intellectual Property - Patent - Biotechnology

\section{INTRODUCTION}

Biotechnological inventions have achieved undisputed importance in industry, agriculture and business, as well as in the promotion of social welfare. Chemical methods previously used have been replaced by others more efficient, based on the use of biotechnological processes, making new products that meet specific demands of human beings.

In human medicine, research relating to the human genome and its mutations has led to better understanding of diseases such as cancer, enabling more accurate diagnoses, even before the manifestation of the symptoms of the disease itself. Similarly, such advances have also contributed to the development of new drugs (pharmacogenomics), as well as on therapeutic medicine (gene therapy), in addition to the creation of DNA (deoxyribonucleic acid) vaccines.

Under these new creations of interest to industry and with 
significant impact on human health, it is observed a legal clash resulting from the imposition of rules and interpretations of the patent system, which is considered relevant to the promotion and guarantee of investments to research and development of new products and technological processes.

If the patent system acquires a strategic importance for research and technological development, the result of research involving living organisms, or parts of them, brings benefits with the adoption of new products, on the other hand, this biopatenting system brings forth the questioning about the possibility of appropriating knowledge based on these natural materials, restricting the innovation in the area.

More specifically, one may question about the suitability of patent protection to the discoveries in biotechnology, especially in regard of isolated biological materials from nature to the research and development of new drugs, as well as the whole or part of the genetic code. Would these materials, in such cases, be considered a creative intellectual work of humans? The genetic code is patentable matter or would it be a mere discovery?

\section{THE MYRIAD CASE}

It is in this context that the United States Supreme Court's decision on June 13, 2013, in the Myriad Case ${ }^{1}$, is gaining importance because of its impact on the interpretation of American law about what would be patentable, mainly in the area of biotechnology. That decision has put to the ground the practice adopted for decades by the United States Patent and Trademark Office (USPTO), since the previous understanding was for the broader possibility of patenting genetic sequences, as well as all material isolated from its natural environment.

Important to note, here, that the analysis of the case does not cause impact only in the patenting of genetic sequences, but also involves all products of nature taken to laboratories to be isolated from its environment, as hormones, vitamins, as well as other extracts. The impact is of such a broad spectrum that Nanotechnology industry participants interfered in the case as amicus curiae to demonstrate their arguments and concerns about the restriction of the patenting of genetic sequences, as nanomaterials are nothing more than isolated products ${ }^{2}$.

1 The Association for Molecular Pathology, et al. v. U.S. Patent and Trademark Office, et al. (US Supreme Court, Process n. 12-398). The US Patent and Trademark Office (USPTO) was removed from the demand later. Besides Myriad, it was also a defendant in the demand the University of Utah/ USA.

2 AMERICAN BAR ASSOCIATION. Available at: http://www.americanbar.org/content/dam/ aba/publications/supreme_court_preview/briefs-v2/12-398_resp_amcu_nano.authcheckdam. pdf. Accessed May 09, 2014. p. 11. 
Basically, the arguments of the parties in the Myriad Case can be summarised as follows, in connection with the genetic sequences:

(i) by the Association for Molecular Pathology: the applications would not be patentable matter as they would not meet Paragraph 101, of Title 35 , of the U.S. Code ${ }^{3}$, i.e. by being true products of nature, as well as the lack of inventiveness. Also, such patents would impede innovation, by reason of the prohibition of conducting research; and would limit the options for the testing of patients with cancer. It was also stressed that the patents on isolated genes would violate the First Amendment of the Constitution of the United States of America ${ }^{4}$ by blocking scientific research on the isolated sequence, since it would be a patent on pure information ${ }^{5}$.

(ii) By Myriad Genetics, Inc. ("Myriad"): the genetic sequences would be liable to protection based on the understanding that they would be chemical compounds. In this sense, the sequence, after the isolation process, would present different characteristics found in the human body. It was also argued that such patents promote innovation in the field of biotechnology, in particular with regard to genetic engineering, to the extent that, by being granted patents, the knowledge is made public, encouraging to not be maintained as business/trade secrets.

Thus, the main issue may be summarized as follows: The isolated genetic sequences are a composition of matter (invention) or occur naturally (discovery) $?^{6}$

In regard to the patenting of genetic sequences, it should be noted that the understanding of the USPTO, with seat in jurisprudence, was that patent protection would be possible only if a substantial change in naturally occurring products was found. In this way, the isolation of the gene sequence would characterize this substantial change.

When the Myriad Case reached the Court of Appeals, all three members issued their opinions; but there was no consensus on the basis of the reasoning.

335 U.S.C. $\$ 10135$ U.S.C. 101. Inventions patentable: Whoever invents or discovers any new and useful process, machine, manufacture, or composition of matter, or any new and useful improvement thereof, may obtain a patent therefor, subject to the conditions and requirements of this title.

4 "Congress shall make no law respecting an establishment of religion, or prohibiting the free exercise thereof; or abridging the freedom of speech, or of the press; or the right of the people peaceably to assemble, and to petition the Government for a redress of grievances".

5 We understand that, although this argument was not clarified in the final decision, it relates to the fact that it is a discovery and, therefore, a basic tool for the genetic research.

6 We clarify that, for Brazilian law, the difference is of great impact, since it cannot be granted a patent on a discovery. 
For example, Judge Lourie understood that, for the examination of the marked difference, little mattered the gene functionality, but only the structural difference, which, for him, existed in the case. Judge Moore understood that the isolated sequence was subject to patenting because of the practice of the USPTO. Judge Bryson found that the isolated gene sequence, even with its proper function identified, behaved in the same way that it behaves in the human body, being absent any new use; in this sense, the patent would be only a consequence of the possession of the sequence?

Because of these controversies, the American Civil Liberties Union (ACLU) and the Public Patent Foundation (PPF), on the proposed action in face of Myriad, have petitioned on September 25, $2012^{8}$, to the U.S. Supreme Court to express an opinion on the possibility of the patenting of genetic sequences, through a petition for writ of certiorari ${ }^{9}$, which on November 30,2012, was admitted, only regarding the question: are human genes patentable?, this being the focus of this work ${ }^{10}$.

The decision, by a majority ${ }^{11}$, came on June 13,2013 , with the

7 Decision of July 29, 2011, Federal Circuit Court of Appeals, Case n. 09-CV-4515 (20101406). Available at: https:/www.aclu.org/files/assets/10-1406.pdf. Accessed June 18, 2014.

8 It is important to note that, for procedural purposes, after the Court of Appeals' decision, on July, 2011, there was the first petitioning to the Supreme Court, which revoked the Federal Circuit's decision, determining the case was revisited according to what was decided on Mayo Collaborative Services v. Prometheus Laboratories Inc. Thus, the case was revisited, taking into consideration the Mayo Case, however in regard to the genetic sequences, such a precedent would not be relevant, since that decision was related to a method. After this second decision, a new petition was addressed to the Supreme Court requesting the specific case of the genetic sequences to be analysed.

9 The writ of certiorari is the principal mechanism of appeal to the Supreme Court in America, for the selection of cases to be submitted to this court. The Supreme Court has the sole power to decide whether or not to analyse the question, taking into consideration a few aspects, such as if there was a prior decision treating important and relevant question that should have been addressed by the Supreme Court, among others. It is based on the necessity of the standardization of understandings regarding the application of the law. PINTO, José Guilherme Berman C.. O writ of certiorari. Em Revista Jurídica, Brasília, v. 9, n. 86. Ago/ Set 2007. Brasília, 2007. Available at: http://www.planalto.gov.br/ccivil_03/revista/Rev_86/ artigos/JoseGuilherme_rev86.htm. Accessed March 12, 2014. The writ of certiorari can be compared to the institute of the general repercussion in the Brazilian law. MELLO, Vitor Tadeu Camarrão. A repercussão geral e o writ of certiorari:breve diferenciação. Revista da SJRJ $n$. 26. Rio de Janeiro: 2009. pp; 139 - 146. Available at: http://www4.jfrj.jus.br/seer/index.php/ revista_sjrj/article/viewFile/32/30. Accessed March 12, 2014.

10 Therefore, as for the other questions that were not accepted by the Supreme Court, acting in its appeal competence, the final decision was the one of the Court of Appeals. Since those questions are in connection with the method and impediment for the realization of tests, these are not going to be analyzed, for they are not the scope of this work.

11 The members of the Supreme Court, by the time of the decision were Judge Clarence Thomas; Judge John Roberts; Judge Anthony Kennedy; Judge Ruth Bader Ginsburg; Judge 
invalidation of the claims contained in the Myriad patents concerning purely isolated genetic sequences based on grounds that they would be products found in nature, remaining valid all claims concerning cDNA (complementary DNA) ${ }^{12}$.

In fact, the Supreme Court used a very specific vocabulary to summarize the issues at stake. It affirmed ${ }^{13}$ that Myriad had obtained several patents after the discovery of the precise location and sequencing of mutations of the BRCA 1 and BRCA $2^{14}$ genes, which determine a dramatic increase in the risk of developing breast and ovarian cancer. Such knowledge has enabled Myriad to develop applicable laboratory tests ("useful medical tests") for the detection of such mutations. If deemed valid, the USPTO would grant the titleholder the exclusive right to isolate the genes BRCA 1 and BRCA 2 of an individual, as well as give Myriad the exclusive right to create synthetically cDNA from BRCA.

The President of the Supreme Court, Judge Roberts, questioning Myriad's lawyer Greg Castanias, in the oral arguments, noted that the isolated organism could not be considered similar to the transgenic organism, since in the latter there would be a combination of elements with the emergence of something new. In the process of isolating a genetic sequence, there would be only the snipping, exposing only a part of something that already existed prior to human intervention ${ }^{15}$; this understanding tended to require the structural difference, necessary for patenting.

Myriad 's lawyer contested that it was not a pure, simple cut, but only after its creation (revelation of the insulation), could the scientist know where to cut.

Stephen Breyer; Judge Samuel Alito; Judge Sonia Sotomayor; Judge Elena Kagan and Judge Antonin Scalia, who did not agree in part with the decision, since he understood that the matter of molecular biology was beyond his knowledge. In his own words: "I join the judgment of the Court, and all of its opinion except Part I-A and some portions of the rest of the opinion going into fine details of molecular biology. I am unable to affirm those details on my own knowledge or even my own belief. It suffices for me to affirm, having studied the opinions below and the expert briefs presented here, that the portion of DNA isolated from its natural state sought to be patented is identical to that portion of the DNA in its natural state; and that complementary DNA (cDNA) is a synthetic creation not normally present in nature."

12 The Supreme Court did not specificaly indicate which claims would be considered invalid. 13 SUPREME COURT OF THE UNITED STATES. Association for Molecular Pathology et al. v. Myriad Genetics Inc. et al. n. 12-398. Syllabus. Available at: http://www.supremecourt.gov/ opinions/12pdf/12-398_8njq.pdf. Accessed June 02, 2014.

14 The BRCA1 and the BRCA 2 (breast cancer susceptibility) are a tumor supressor human genes that regulate the cellular cycle and prevent the uncontrolled proliferation. Some variations or mutations of those genes are associated with an increase of the risk of breast cancer.

15 Oral Arguments in the Myriad Case, available at the Supreme Court's website, page 61. Available at: http://www.supremecourt.gov/oral_arguments/argument_transcripts/12-398amc7.pdf. Accessed June 02, 2014. 
The invention would be in knowing where to start and where to finish the gene sequence (where to cut the rest of the chromosome). Myriad 's lawyer used the analogy of the baseball bat: Similarly, the baseball bat was cut from a tree, that is, it is also found in nature, but the decision about where to start and where to finish was taken by humans. Roberts argued that such analogy would be quite different, since, with the DNA, these are mere cut on top and bottom.

Still, Castanias noted that the location of genes, contained in subparts of the chromosome, was unknown until its isolation among the 8 million pairs of nucleotides. At most, the breaking of chemical bonds, when the isolation process occurs, gives a different structure to the isolated DNA.

Following the questioning, Judge Breyer said that, historically, it is recognized the patenting on the process for extracting a substance from a plant, as well as the new uses that can result from such extract, but the extract itself cannot be patented, which encourages new uses to be developed by science.

Judge Kagan questioned how it would be if the first person who found and isolated a chromosome had it patented; as well as the first person who found a liver had it patented, and so on. Myriad 's lawyer replied that there would be no obstacle to patentability with regard to the already mentioned $\S 101$.

Chris Hansen, a lawyer on behalf of ACLU, argued that there could be something different from nature and not obvious when the genes were transformed in a way that the scientist decided what it would be like the sequel more than the very nature, which wouldn't be the case.

The Supreme Court understood, then, that the main contribution of Myriad was only revealing the precise location of the genes BRCA1 and BRCA2, but thise sequences did not present markedly different characteristics than those found in nature. Myriad would have discovered an important and useful gene, but the discovery, even if innovative and brilliant, does not meet, per se, the legal patenting requirements. Still, the exhausting process of such a discovery does not meet the requirements of patentability, in the same way, because already known and used widely by the scientific community.

So, to the Supreme Court, the isolated gene sequence would be purely a product of nature not worthy of patent protection. However, the cDNA, a synthetic DNA containing coding portions only, i.e. the exons, does not occur naturally, and could receive protection, not being invalidated claims based on cDNA, except in the case of short sequences of cDNA that do not differentiate substantially from the natural DNA (where there were no introns to be removed). 


\section{AN ANALYSIS OF THE DECISION}

The genetic sequences are an essential tool for fully comprehending living beings, for they encompass all necessary information for their operation, being the basic and fundamental pieces for all that lives.

The requirements for obtaining a patent in the United States are described in Title 35, Paragraph 101, of the U.S. Code, i.e. the invention must be a new and useful process, machine, manufacture or composition of matter, considering a broader interpretation with 3 limitations: the laws of nature, the natural and physical phenomena and the abstract ideas, since those would be basic tools for science, therefore, not subject of appropriation.

In this sense, an invention must: (a) be new; (b) have a utility and (c) not be obvious. In general, we discuss the possibility of patenting 3 basic genetic materials: a) the natural DNA, found in nature, identical to the natural product; b) the isolated DNA, which is the natural DNA with the removal of the histone ${ }^{16}$ so the sequence (containing the entire gene for a given function) is detached from the chromosome structure; c) the cDNA, which is a synthetic DNA containing only the coding regions for proteins present in the DNA (an exon-only DNA).

In general, when a gene is activated, the sequence is read and copied in the transcription process ${ }^{17}$. Once the transcription process is initiated, the histone proteins must be broken and the DNA strands are separated in the transcription bubble. Note that, at this moment, the natural DNA strand resembles the isolated DNA, even structurally.

Then, the copy of the genetic material is synthesized in a RNA (ribonucleic acid). In sequence, the RNA has its structure modified, including the removal of introns, so that the mRNA (messenger RNA) is created. During the translation process, the mRNA codons are read so that a specific amino acid is incorporated into the protein originated from the nucleotide sequence inside that codon.

The mRNA during translation or protein synthesis, leads to the incorporation of protein amino acids through their codons.

In the creation of cDNA, the reverse transcriptase enzyme is applied on the segment of the mRNA, and, as from a completely natural process, the cDNA is synthesised. Note that the sequences are complementary to each other.

The first argument is that, in the synthetic preparations of biological materials, there is a transformation of the DNA molecule

16 Proteins comprising the nucleosome, which function as the matrix in which DNA is wounded. 17 BOWMAN, Andrew. Genes 101: Are human genes patentable subject matter?. XVIII RICH. J. L. \& TECH. 15. Available at: http://jolt.richmond.edu/v18i4/article15.pdf. Accessed April 17, 2014. p. 17. 
by human intervention into something structurally and functionally different from its natural correspondence. This is because the desired sequence is removed from the remainder of the chromosome requiring the breaking of covalent bonds between the chromosome and its DNA and such chemical alterations promote the creation of a new molecule that does not exist in nature. There is a chemical change in the molecular level, with a modification in the composition of substances (in a physical change, there would be difference in appearance, odor, and no change in the composition). The isolated sequences do not have the regulatory regions; therefore, they are chemically different (different in structure).

Still, some consider that there is a functional difference in so far as they provide a new use of the natural sequences, which can not be manipulated and controlled in the same way. This is a justification, considering a new use.

However, Andrew Bowman ${ }^{18}$ suggests that both structural and informational differences should be analyzed, in order to respect the judicial exception of the products of nature. For him, one must adopt the posture of the totality of the circumstances approach. Thus, two perspectives would have to be considered: a chemical perspective and a biological one.

From a chemical point of view, the analysis of the molecular structure is relevant. In this respect, there is a clear difference between the three genetic materials under discussion, since all cases involve the chemical breakdown.

Under a biological perspective, one must analyze the information that the structure reveals. In this case, there is no substantial difference between natural DNA and the isolated DNA since the genetic information encompassed, in both cases, is still the same.

According to Bowman ${ }^{19}$, in order for a difference to exist, the isolated DNA sequence should encode a protein sufficiently different from that found in nature. However, for him, the cDNA would be subject to patenting, which is in accordance with the decision of the Supreme Court, although, in the end, it encodes the same protein. It states that the mature mRNA undergoes significant changes during transcription, specifically in regard to the removal of introns. In the "production" of the cDNA, a synthetic DNA is created, being composed only of exons.

Among the three materials, it is easily observed a molecular structural difference, but it must be verified if, in essence, there is a difference in the genetic information they contain.

18 BOWMAN, Andrew. Genes 101: Are human genes patentable subject matter?. XVIII RICH. J. L. \& TECH. 15. Available at: http://jolt.richmond.edu/v18i4/article15.pdf. Accessed April 17, 2014. p. 18.

19 BOWMAN, Andrew. Op. cit. p. 22. 
Judge Bryson ${ }^{20}$, in his aforementioned opinion, refers to the example of minerals and leaves or plants taken from their origin. In such cases, there may be, the same as in the case of the isolation of the DNA segment, too much trouble and difficulties in the isolation process, but it does not mean that it is patentable subject matter. This is because the leave was created by nature, as well as the genomic DNA. For the isolated material to be patentable one must visualize an additional step that is not superfluous, that is more than conventional, obvious, routine or insignificant.

It is not hard to see the structural difference between the three indicated genetic materials. For example, the BRCA 1 is only 1 of 1773 genes in the population of 81 million nucleotides of chromosome 17; BRCA 2, in turn, is one of the 720 genes that make up the 115 million chromosome 13's nucleotides ${ }^{21}$. The isolated sequence has 7 thousand for the BRCA 1 and 11 thousand pairs, for BRCA2.

As for the chemical structural difference between natural DNA and the isolated DNA, the Supreme Court held that the breaking of chemical bonds would be sufficient to characterize the marked difference of the product of nature.

In regard to the material, functional or biological difference between the natural DNA and the isolated DNA, the US Supreme Court understood that they are not distinguished from each other. The Supreme Court determined that the isolated sequences do not deserve protection, given that they are essentially indistinguishable from the relevant portion of the DNA in question, encompassing the same genetic information.

In concern with the cDNA, which is an exon-only fragment of DNA, the Supreme Court understood that there is a difference from nature. Exons are the DNA fragments necessary for the creation of a protein; they differ from the introns, which do not encode any protein. But, for a protein to be created, the DNA must be transcribed into RNA, which is complementary to this sequence - this is the standard cell pattern. However, this is still not enough, and this pre-RNA, containing non-coding introns, has to be converted into mRNA, with the removal of introns (splicing). This resulting mRNA is then translated into protein.

Obviously, themRNAcannotbepatented, beingaproductofnature. From this mRNA, rather than translating into the protein, scientists use it to create a sequence complementary to it, which is the cDNA. Thus, since the cDNA is synthesized from mRNA, it contains only the coding sequences, i.e., the exons, differing structurally from the natural or the isolated sequence, which contains both introns and exons. The cDNA then acts as a double-stranded mRNA, being more stable in

20 Judge Bryson's opinion. Available at: http://www.cafc.uscourts.gov/images/stories/opinionsorders/10-1406.pdf. p. 88. Accessed April 17, 2014.

21 BOWMAN, Andrew. Op. cit. p. 9. 
vitro. However, this is merely temporary, since, once available to use for screening genes or sequences, for example, it is immediately broken, becoming a single stranded structure.

From a hereditary standpoint, it functions as an mRNA containing the same genetic information. Biochemically, namely in terms of structure, the mRNA differs only by the presence of ribonucleic acid rather than deoxyribonucleic acid and the presence of the nitrogenous base uracil instead of thymine present in DNA.

Now, one can not deny the structural difference is clear, but it is nothing more than a mere shift in the coding of the protein, as both the chromosomal DNA, the isolated sequence and the encoded protein, would be considered products of nature, therefore, not patentable. Scientists just created a new step to allow the patenting; they created a subterfuge to the impossibility of patenting the DNA and the mRNA. At the most, these are all processes and products predetermined by nature. That isafter examining the procedure of the cDNA's synthesis, one may find that it is nothing more than a sequence complementary to the mRNA, which is found naturally. This is because the laws of nature predetermine its sequence and function.

It can be concluded then that cDNA is nothing more than an obvious consequence of the mRNA, which occurs naturally; as well as the isolated sequence is a consequence, also obvious, in the purification process.

Still, it should be noted that, in the same way that the isolated sequence is, the cDNA is a basic tool of genetic engineering, preventing, at least to American law, researches based on that cDNA, which is not beneficial to the scientific and technological development. The very decision of Judge Robert Sweet in the 1st instance on the Myriad Case ${ }^{22}$, referring to the isolated sequences, based on arguments raised by the scientific community involved, decided that the patenting of those would be a cool trick to circumvent the ban on patenting the natural genetic code. Similarly, the cDNA patenting is a mockery of the impossibility of patenting the natural code and isolated sequence - what happens is the mere displacement of the impossibility barrier. One can not deny the usefulness, but that use is not greater than that found in nature.

\section{THE BRAZILIAN LAW STANDPOINT}

Brazilian patent law seems to leave no room for doubt, denying categorically the possibility of patenting the isolated gene sequences, including the genome, in art. 10, IX, of the Brazilian Patent Law n. 9279/96

22 BEAUCHAMP, Christopher. The pure thoughts of Judge Hand: A historical note on the patenting of nature. Available at: http://www.law.nyu.edu/sites/default/files/ECM PRO_071307.pdf. Accessed May 09, 2014. p. 3. 
(LPI). However, this does not mean one can not determine whether such sequences would be or not actual inventions and would not be the case to adapt the legislation to the American model of interpretation.

The national constitutional principle underlying the industrial property is in item XXIX of Article 5, stating that "the law shall ensure the authors of industrial inventions a temporary privilege for their use, as well as protection of industrial creations, property of trademarks, the company names and other distinctive signs, in view of the social interest and the technological and economic development of the country"23.

The Agreement on Trade-Related Aspects of Intellectual Property Rights (TRIPs), of which Brazil is a signatory, states that:

Art. 7. The protection and enforcement of intellectual property rights should contribute to the promotion of technological innovation and to the transfer and dissemination of technology, to the mutual advantage of producers and users of technological knowledge and in a manner conducive to social and economic welfare, and to a balance of rights and obligations.

Art. 8, 1. Members may, in formulating or amending their laws and regulations, adopt measures necessary to protect public health and nutrition, and to promote the public interest in sectors of vital importance to their socio-economic and technological development, provided that such measures are consistent with the provisions of this Agreement.

The Brazilian Constitution ensures the fundamental right of a protection to guarantee the authors of industrial inventions, and it is up to infraconstitutional law to simply clarify what would or would not be an invention. However, the exclusion of protection of certain inventions by mere legislative policy, although possible and accepted, if made without any basis in the protection of another fundamental right, may violate the constitutional provision that guarantees the right of inventors.

Verifying Art. 5, XXIX, of the Brazilian Constitution, in its final part, there is a purpose to be respected. This finalistic clause shows that the rights relating to industrial property are not derived directly

23 This purpose clause is also found in the US Constitution: Art. I, S 8, cl 8. Constitution of the United States. Powers of Congress. The Congress shall have power: to promote the progress of science and useful arts, by securing for limited times to authors and inventors the exclusive rights to their respective writings and discoveries. 
from the Constitutional text, but rather from the infraconstitutional law, which will only be in accordance with the Constitution if the objectives of (i) targeting the corporate interest of the country (public interest); (ii) promoting technological development of the country; and (iii) promoting the economic development of the country are met.

There is some controversy regarding the language "in view of the social interest and the technological and economic development of the country", contained in item XXIX, of Art. 5, of the Brazilian Constitution, if it would have an evaluative-finalistic content or more of a determinative-conditional content - i.e. if it determines the granting of a patent or if it orientates its purposes. It is understood that one does not exclude the other. In this sense:

In regard to item XXIX, Art. 5 of the Brazilian Constitution, the expression "in view of the social interest and the technological and economic development of the country" appears imprecise as to the content that you should report. If not so, one should not discuss it to be indicating an evaluativefinalistic content or conditional. ${ }^{24}$

Gustavo Tepedino ${ }^{25}$ adds that even if industrial (intellectual) property has an artificial content, it must, in any event, take account of the social function or purpose, conditioned such subjective legal situations to all relevant social interests and developments of the human personality:

Thus, trademarks, patents and all expressions of so-called "intellectual property" are artificially developed under the molds of a proprietary status, just to attract the protective efficacy that is attributed to private property. Also, in these cases, however, one can not fail to mention the social function which must be performed by these new subjective legal situations, which must also be contingent on the relevant social interests and development of the human personality, greater purpose of our civil and constitutional system.

This should be understood as the very social function of

24 GRAU-KUNTZ, Karin. Direito de patentes: sobre a interpretação do art. $5^{\circ}, X X I X$, da Constituição Brasileira. Available at: http://www.newmarc.com.br/ibpi/d pat.html. Accessed May 23, 2014.

25 TEPEDINO, Gustavo. A garantia da propriedade no direito brasileiro. Available at: http:// fdc.br/Arquivos/Mestrado/Revistas/Revista06/Docente/04.pdf. Accessed May 26, 2014. 
industrial property law, despite the controversy surrounding its legal status or nature. Technological progress is achieved and free competition guaranteed, when the patent system works (a) as a stimulus and encouragement to inventive activity; (b) as an incentive to the disclosure of technical information generated for the production of the invention by the inventor to the public, because of the contribution to the prior art; and (c) as encouragement to the spread of inventions, there is a balance in the rights conferred by the patent ${ }^{26}$.

Thus, when the infraconstitutional law deviates from the possibility of patenting certain inventions (considering that falls within the doctrinal and factual concept, but not legal) which could mean a breakthrough in technological and economic development of the country, one can understand that such legal discrimination is in dissonance with the Constitution, since it neglects the interests of the technological and economic development ${ }^{27}$.

Any restriction to a fundamental right (as is the right of inventors, in Art. 5, XXIX, of the Brazilian Constitution) shall comply with the principle of proportionality. Therefore, it is not a simple privilege established by law which must be interpreted narrowly, but a freedom or a fundamental right guaranteed as such, that should be interpreted broadly ${ }^{28}$. That is, a true balance of interests between the right to patent protection, free competition, freedom of initiative and the right to scientific and technological development must be pursued.

When there are one or more fundamental rights at stake - in this case, the right to protection of intellectual property, the value of free enterprise, free competition and the right to scientific and technological development - should they suffer weighting process due to the value they want to protect. In other words, it is possible that fundamental

26 DIAFÉRIA, Adriana. Patente de genes humanos e a tutela dos interesses difusos: o direito ao progresso econômico, científico e tecnológico. Rio de Janeiro: Lumen Juris, 2007. p. 176.

27 We clarify that, according to Adriana Diaféria, the final part of item XXIX, of Art. 5, of the Brazilian Constitution does not indicate only a social function to be attended, but a true right of the collectivity. To her, "it is presupposed in the granting of private industrial property rights which aims to ensure the possibility of absolute exercise of rights to an invention - the protection of a higher legal interest which is the technological, economic, and, in consequence, scientific interest of the country (Art. 5, XXIX, CF). (...) The right of the inventor/patent holder and the right of the community to advance economic, scientific and technologically (...).’DIAFÉRIA, Adriana. Patente de genes humanos e a tutela dos interesses difusos: o direito ao progresso econômico, científico e tecnológico. Rio de Janeiro: Lumen Juris, 2007. p. 158.

28 We highlight that it is also a freedom, such as the freedom of initiative or the freedom of competition, and, in that sense, one should not simply apply the interpretation of rules system but the principles weighting system. 
rights are restricted, and such restrictions are subject to limitations ${ }^{29}$.

Thus, the balance of interests must be undertaken from the perspective of proportionality, which is composed of the subprinciples of suitability, the subprinciple of the need for such measure and the subprinciple of proportionality in the strict sense. The principle of proportionality serves as a parameter to gauge the conduct of the legislature when it concerns limitations to fundamental rights, such as the limitation imposed by infraconstitutional legislation (art. 10 and 18, of the LPI) on the rights of inventors (Art. 5, XXIX, of the Brazilian Constitution).

In this sense:

[...] The fundamental right to patent protection in Brazil is subject only to restrictions arising from a qualified legal reserve, as provided in Art. $5^{\circ}$, $X X I X$, of the Constitution. Thus, the legal regulation of such right, operated by Law No. 9,279 / 96, (...) is subject to a constitutional filtering threefold: (i) formal: a formal Law is required for regulation; (ii) express content: the requirement that the regulatory law has "the social interest and the technological and economic development of the country" in view; (iii) of subtext: the requirement that the regulatory law performs, thoughtfully, an accommodation between the constitutional values involved in right to patent protection, seeking a great point of maximum achievement of them all; moreover, the law must respect, in the weighting, the core of the intellectual property right, without which there is no limitation, but a true suppression of the fundamental right. ${ }^{30}$

The first issue to be addressed is the subprinciple of suitability, which consists on the adequacy of the measure adopted to achieve the intended purpose, i.e., there must be consistency in the means-end relationship. "The adequacy of means to ends translates into a requirement that any restriction must be suitable to achieve the persecuted purpose because if it is not able to do so, is to be considered unconstitutional." 31

29 BARROS, Suzana de Toledo. O princípio da proporcionalidade e o controle de constitucionalidade das leis restritivas de direitos fundamentais. $2^{\mathrm{a}}$ ed. Brasília: Brasília Jurídica, 2000. p. 160.

30 GAMA JUNIOR, Lauro; e BINENBOJM, Gustavo. O direito à proteção patentária como direito fundamental: interpretações sistemática, teleológica, constitucional e internacional. Available at: www.mundojuridico.adv.br/cgi-bin/upload/texto820.rtf. Accessed May 23, 2014. 31 BARROS, Suzana de Toledo. Op. cit. p. 76. 
Thus, limitations of public policy on property rights or privilege, understood also as a fundamental right in our constitutional order, must be in the exact measure to ensure free competition and technological development.

As for the subprinciple of the need of such measure, the restrictive measure is essential to the conservation of itself or another fundamental right that can not be replaced by another equally effective, but less onerous measure.

In regard to intellectual property rights, one must pay attention to the fact that they should be granted broadly, given that there are more effective means of control without presuming the abuse of patent holders, namely, the compulsory licensing, under Arts. 68 and following, of the LPI.

If there are equally effective means, but less harmful or restrictive, that permit the achievement of the same goal, the measure is not reputable - that is, to impose legal limitations on what fits perfectly into the category of invention, being possible for the state to control the use of the privilege granted by the compulsory license, as well as with the possibility of not to impede research, even by legal provision, pursuant to Art. 43, II, LPI, it is not appropriate to exclude that category of invention from the concept of invention by mere public policy. What is meant is that there are other ways of performing the public policy that do not simply seal the possibilities of patenting.

The measure "is required when the legislature could not have chosen otherwise, another equally effective measure that would not limit or limit in the least significant way the fundamental right." 32

In reference to the proportionality in the strict sense subprinciple, the matter is to indicate whether the measure used is in reasonable proportion to the end pursued, in regards to the idea of balance between the values and assets.

In the specific case of gene sequences, we should take into consideration, then, assuming that there really is an invention at stake ${ }^{33}$ :

(i) If the exclusion of the possibility of patenting, based on

32 BARROS, Suzana de Toledo. Op. cit.. p. 80.

33 We clarify that regarding the genetic materials, the isolated sequences are not a true invention, for they are mere products of nature; however, the synthetic cDNA, based on the understandings of the Supreme Court, is a true invention. We reserve our understanding that the cDNA encompasses the same genetic information as the mRNA and its stability does not confer it a sufficient marked difference. As for the recombinant DNA, we understand that it is a true invention, although the recombined protein may not be. As for the other biological materials, one should verify the structural and functional difference in order to verify if they are different from nature. If it presents a marked difference, it should be considered a true invention. It should also be taken into consideration if the public policy rules exclusions from inventions are really legit regarding the interests pursued by law. 
needs of public policy, a true invention is a suitable measure to achieve the social interest and the technological and economic development of the country;

(ii) If that occurs, whether there are alternative means to such exclusion, and less onerous to the fundamental right in question that are also able to achieve the same purposes;

(iii) If this also occurs, if the degree of importance of holding the ends justifies the degree of restriction imposed on the fundamental right at stake.

This is because the first step to be taken in accordance with national law is to check if the supposed creation is an actual invention, according to Art. 10, I, of the LPI. Thus, the analysis must begin with the distinction between discovery and invention, even for the inspection of the legislative limit of interference in the sphere of the fundamental right of the inventor. In this sense, it is recommended that, since the possibility of patenting some genetic materials may signify a market advantage in the pharmaceutical industry, studies should be conducted in order to determine how much they mean to the technological and economic development, in order to be proposed or not a modification in the Brazilian legislation.

We understand that if there is a competitive advantage in the patenting of these materials, attracting players and investment to countries that grant the patent, it should be made a change in the national practice, so we can offer a more competitive market on the same terms. The IMD World Competitiveness Center, pioneer in the field of Competitiveness of Nations and World Economy Ranking, considers, as a subfactor, in Infrastructure (Scientific Infrastructure), the number of patent applications, patent grants, number of patents in force, intellectual property rights, laws relanting to scientific research to encourage innovation as factors to evaluate the competitiveness of a country. In 2014, the United States of America was placed in the first position, while Brazil was placed in the $54^{\text {th }}$ position, among 60 countries of various levels of development ${ }^{34}$.

That is, the limitations of law, by public policy, on the patenting of inventions, such as Art. 10, IX, and Art. 18, III, both of the LPI, without any support in meeting the social function of promoting scientific and technological development, should be avoided.

With respect to the LPI, it expressly enunciates what can not be patented, either because it is not an invention, either by a prohibition. Such restrictions must be interpreted strictly in order to limit the possibility of the inventor's fundamental and constitutional right. That is, in principle, everything is an invention, unless those exclusions

34 Available at www.imd.org/uupload/IMD.WebSite/wcc/WCYResults/1/scoreboard_2014.pdf. Acessed May 11, 2015. 
listed in Art. 10 of the $\mathrm{LPI}^{35}$. Thus, as a rule, all technical solution to a technical problem (invention) which is new, not obvious to one skilled in the art, and which allows unlimited reproduction without human intervention in each case is an invention ${ }^{36}$.

Also, the language in Art. 18, of the LPI, by not considering a few creations as inventions, intends to repute the granting of the privilege in a broader sense, since every and all inventions not mentioned in the legal prohibitions should be patentable subject matter ${ }^{37}$.

In this sense:

Art. 10. It should not be considered inventions or utility models: (...)

Art. 18. It shall not be patentable subject matter: (...)

Denis Borges Barbosa, contrary to the above proposed, affirms that the laws that grant patent rights should be strictly interpreted, taking into account the reasonableness and prudence applicable to the case $^{38}$. This is because the freedom of initiative is the greater purpose of the law and that all exceptions to that, such as the intellectual property rights, should be interpreted in a strict sense ${ }^{39}$. The author bases his position on Diogo de Figueiredo's teachings ${ }^{40}$ :

[...] The principles that define freedoms prefer to the ones that condition or restrict them; and the ones that grant powers to the State yield to the ones that reserve powers to individuals, and the ones that reinforce the spontaneous order are preferred over the ones that derogate it.

The freedom is obviously of initiative and information,

35 BARBOSA, Pedro Marcos Nunes; BARBOSA, Denis Borges. O Código da Propriedade Industrial conforme os Tribunais - comentado com precedentes judiciais. Furnished by the authors, via e-mail, on December 13, 2013. p. 6.

36 BARBOSA, Pedro Marcos Nunes; BARBOSA, Denis Borges. Op. cit.. p. 7.

37 DEL NERO, Patrícia Aurélia. Propriedade Intelectual: A tutela jurídica da biotecnologia. São Paulo, SP: Ed. Revista dos Tribunais, 1998. p. 78.

38 BARBOSA, Denis Borges. Relatório de Análise da incorporação do conhecimento levantado e sua possível aplicação no Brasil Contrato n. 2010/000426. PROGRAMA DAS NAÇÕES UNIDAS PARA O DESENVOLVIMENTO. SERVIÇOS DE CONSULTORIA. PROJETO PNUD/ BRA/06/032. BRASÍLIA. Termo de Referência $n$. 133963. Furnished by the author, via e-mail, on December 2013. p. 14.

39 BARBOSA, Denis Borges. Op. cit. p. 15.

40 MOREIRA NETO, Diogo de Figueiredo. A ordem econômica na Constituição de 1988. Revista da PGE-RJ, n. 42, p. 59. Apud BARBOSA, Denis Borges. Op. cit.. p. 15. 
impeded by the privileges and exclusive rights. The spontaneous order is the free flow of ideas and creations, and the spread of technology.

The author also cites the work of Carlos Maximiliano ${ }^{41}$, affirming that the Brazilian Civil law ${ }^{42}$ explicitly consolidated the classic precept - excepctiones sunt strictissimae interpretationis ("the exceptions are to be interpreted in the most strict sense"). He continues his thought, stating that the same guidance should be given to the rules that grant a privilege to certain people.

In general, for the isolated sequences, these would be mere discoveries for not having any difference from the products of nature, as already explained. Thus, even if there were no legal exclusion in the item IX, of Art. 10, these materials would not be considered as an invention, being mere discoveries, they would be already excluded based on the item I.

Denis Borges Barbosa also points out that the exclusion from patenting of the isolated materials should be in the language of Art. 18, of the LPI, for this would be an exclusion based on public policy:

[...] One can not decree what is or is not an invention,
since it is a matter of fact-in a classic definition-being
a technical solution to a technical problem. The language
in Art. 10 indicates this notion, but it can not determine,
for example, that a knowledge that leads to a technical
solution to a technical problem is no longer an invention.
The law can make something that is an invention to not
be patentable; but the locus for this is in Art. $18^{43}$.

We understand that, technically, the association of a particular gene sequence to its function implies a mere discovery - a mere revelation of its function. This discovery, although extremely important, is a progress that must integrate the scientific knowledge basis - that is,

41 MAXIMILIANO, Carlos. Hermenêutica e Aplicação do Direito. $15^{\mathrm{a}}$ ed. Forense: Rio de Janeiro, 1995. p. 225.

42 This understanding is in connection with the 1916 Brazilian Civil Code, which was revoked by Brazilian Civil Code of 2002. However, the Brazilian Civil Code of 1916 being substituted by the 2002 Code has no impact to this position, since it is a principle for the interpretation for laws widely preserved.

43 BARBOSA, Denis Borges. Relatório de Análise da incorporação do conhecimento levantado e sua possivel aplicação no Brasil Contrato n. 2010/000426. PROGRAMA DAS NAÇÕES UNIDAS PARA O DESENVOLVIMENTO. SERVIÇOS DE CONSULTORIA. PROJETO PNUD/ BRA/06/032. BRASÍLIA. Termo de Referência $n$. 133963. Furnished by the author, via e-mail, on December, 2013. p. 14. 
it only proves what already is in nature. Moreover, the use of a sequence in a specific process or product that is not obvious (not based only in the identified function) could be regarded as an invention, but not the isolated sequence itself - it is a mere discovery.

So, in summary, for the isolated gene sequences, there is a categorical prohibition and, in our view, they would be mere discoveries.

For the other products found in nature, it should be verified in a case to case basis if there is a structural and functional difference from the product of nature.

We also emphasize that not everything found in nature is organic, as it involves the meaning of "life". Therefore, when the language in item IX, Art. 10, of the LPI excludes only the "biological materials found in nature", it leaves room for the appropriation of non-organic products found in nature. Certainly, these products could not be patented because they are mere discoveries, if not present a structural and functional difference, but there is a legislative atecnia that could be avoided by simply deleting the item IX of Art. 10 of the LPI.

Another point that can be highlighted is that the LPI also states that "the genome or germplasm of any natural living being and the natural biological processes" are also not patentable. Thus, a first conclusion about the possibility of patenting in the Brazilian legislation is that we may patent the genetic sequence of a non-natural living being. For that matter, natural beings are the products of nature (those that occur naturally and have not been the result of human inventiveness). Consequently, nonnatural beings would be those that would not occur naturally and are not found in nature. As an example, the genetically modified organisms. Thus, the gene sequences, with identified functions, from genetically modified organisms could be embraced by the patent, since not included in the categorical prohibition. Another possibility of patenting would be the recombinant DNA, and sometimes, if distinct from the one found in nature, the recombinant protein.

As for the synthetic cDNA ${ }^{44}$, structurally distinct from the natural DNA, we understand that it contains the same genetic information as the mRNA, which is a product of nature, and does not meet the concept

44 We highlight that cDNA is a necessary step in most researches, then being necessary and obvious. "Among the technologies for the analysis of the gene expression, widely used, the most used and economic viable, in terms of quantity and quality of the generated information, are (i) the large scaled sequencing of cDNA libraries, that generate the information known as EST (expressed sequence tags); (ii) the technology known as SAGE (serial analysis of gene expression); (iii) DNA microarrays or chips (...) The (cDNA) libraries are prepared from isolated mRNA from interest samples, by using the reverse transcriptase enzyme, that generates a DNA complementary to the mRNA" MARQUES, Marilis do Valle; SILVA, Aline Maria da. Genômica funcional: transcriptoma. In MIR, Luís (org.). Genômica. São Paulo, SP: Atheneu, 2004. p. 123. 
of invention.

However, since in the international scenery the cDNA has been accepted as patentable subject matter, we recommend giving this material such treatment, in order to reach homogenization regarding the theme and approximating Brazil in terms of competitiveness.

We also stress that, according to Art. 18 of the LPI, which states the prohibition of patenting a few inventions in regards to public policy, it includes in such prohibitions all or part of living beings, and we could interpret such prohibition to include the genetic sequences as part of living beings.

Art. 18. It shall not be patentable:

III - the whole or part of living beings, except transgenic microorganisms that meet the three patentability requirements - novelty, inventive step and industrial application - provided for in Art. 8 and which are not mere discoveries.

Sole paragraph. For purposes of this Law, transgenic microorganisms are organisms, except the whole or part of plants or animals that express, through direct human intervention in their genetic composition, a characteristic normally not attainable by the species under natural conditions.

However, this would be a broad interpretation on a restriction to a fundamental right, as seen previously, which should not be accepted. That is, to the restriction it must be given the strictest interpretation that meets the objectives of the law. Therefore, it is not possible to interpret the genetic sequence as a part of a living being, because when the law refered to the genome or genetic sequences, even generically, it did explicitly (Art. 10, IX, and Sole Paragraph of Art. 18, both of the LPI).

In summary, (i) natural or isolated sequences are not an invention; (ii) other biological materials found in nature merely isolated are not an invention; (iii) biological materials that are not found in nature may be an invention (e.g., genetically modified); (iv) non-biological materials merely isolated and found in nature are discoveries and could not be patented; (v) non-biological materials, even if found in nature, could be patented, if they meet the structural and functional difference requirement (marked difference); (vi) the cDNA, which is a biological material (despite our reservation, since, in our view, it would be technically a discovery, however, is not the understanding that has prevailed in American jurisprudence), has been understood as an invention and should not be 
confused with the concept of genome and can, therefore, be patented anyway, it is not a natural material, but rather synthetic - that is, there is no express prohibition in Brazilian law; (vii) the recombinant DNA is an invention and can be patented as it is not a natural material. On the other hand, the recombinant protein that is identical to the one found naturally would not be considered an invention.

The contribution of the Myriad Case for the interpretation of Brazilian law is, given that it established the specific basis for the classification of some genetic materials as discoveries or inventions, it facilitaded the interpretation of Brazilian law. It is so that the Brazilian Patent and Trademark Office (BPTO) has issued new guidelines for the analysis of the patentability of biological materials, which will be addressed to later.

The parameter of interpretation of the law by the BPTO must take into account the principle of legality.

If the current legislation excludes the possibility of patenting biological materials found in nature, even if isolated, including the genome, the administrator can not grant patents for isolated sequences. On the other hand, we do not see in the law, a categorical prohibition for the patenting of the recombinant DNA, the cDNA and the recombinant protein, if present the marked difference.

Chemical compounds found in nature do not suffer protection, pursuant to sections I and IX of Art. 10 of the LPI. Also, the chemical compounds obtained synthetically that match the naturally occurring compounds without distinction are not considered as an invention, in accordance with the provisions of item I of Art. 10 of the LPI, if not biological, or in item IX, if organic.

On November 2012, the BPTO has made available for public consultation the new Patent Applications Examination Guidelines for the Biotechnology Area ${ }^{45}$, finally approving, on March 12, 2015, the Resolution 144/2015, establishing the new Order of Examination Guidelines for Patents in the Biotechnology Area ("Guide").

According to this new Guide, in section $1.1^{46}$, which deals with the industrial application requirement, we find that the BPTO believes that the isolated gene sequence with the identified function as a marker to diagnose prostate cancer, for

45 INPI. Diretrizes de Exame de Pedidos de Patente na Área Biotenológica. Available at: http:// www.inpi.gov.br/images/docs/diretriz_biotecnologia_consulta_publica_30_11_12_original_0. pdf. Accessed May 27, 2014.

46 The genetic sequences even have their own eletronic listing system, under Administrative Order n. 81/2013. Available at: http://www.inpi.gov.br/images/docs/resolucao_81-2013_listagem_de_sequencias.pdf. Accessed May 27, 2014. And also Administrative Order n. 229/09. Available at: http://www.inpi.gov.br/images/stories/Resoluo_228-09-ANEXO.pdf. Accessed May 29, 2014. 
example, meets the industrial application requirement by clearly revealing a practical use. But it does not state that it is an invention. Still, in item 4 of the Guide, we have access to the concepts and understandings of the BPTO on the legal text (subsection 4.1), relating the subject matters excluded from patent protection. In this sense:

the "whole" (of natural living beings) refers to plants, animals, microorganisms and any living being;

"Natural part of living organisms" refers to any portion of the living beings, such as organs, tissues and cells;

"Biological materials found in nature" include all or part of living beings, and extracts, lipids, carbohydrates, proteins, DNA, RNA, or parts or fragments thereof as well as any substance produced from biological systems, for example hormones and other secreted molecules, viruses, prions. It is worth mentioning that synthetic molecules identical or indistinguishable from their natural counterparts are also contained in this definition;

By "isolated from nature" means any material extracted and subjected to a process of isolation and / or purification;

"Genome" is the set of genetic information of a cell, organism or virus;

"Germplasm" is the hereditary material set of a representative sample of individuals of the same species.

"Natural biological process" is any biological process that occurs spontaneously in nature and where human intervention does not affect the final result.

Analyzing the item that encompasses organic products, item 4.2.1.1, we find that such products even if produced synthetically, to receive patent protection, may not correspond to a naturally occurring product. Thus, because they are merely isolated products, they lack of 
protection. However, if they are enriched, they would be eligible for protection when they have reached characteristics that are not found usually in the species and are based on direct human intervention.

The section 6 of the Guide deals specifically with biological sequences, such as nucleotides, amino acids and proteins. In such section, we note that the BPTO indicates that some requirements should receive special attention, namely: 1) the need to include the biological sequence in the patent application in order to meet the sufficient description requirement (Art. 24); 2) natural occurrence (Art. 10, IX).; 3) clarity, precision and justification (Art. 25) in the way such molecules/sequences are claimed; 4) novelty (Art. 11); 5) inventive step (Art. 13); and 6) industrial application (Art. 15).

We emphasize that the novelty requirement, when related to biological sequences, follows the same general principle, namely, that a sequence of amino acids or nucleotides to not be considered new, face to the prior art, all nucleotides or amino acids should be exactly the same and be in the same order as the sequence known in the state of the art. The nucleotide sequences may be referred to in patent applications in different ways: genes, vectors, plasmids, DNA sequence, RNA sequence, nucleic acid, oligonucleotides, primers, cDNA, and others.

There are different ways to make changes in the nucleotide sequences in order to differentiate them from their natural sequences, and the simple insertion of the term "recombinant" is not sufficient to distinguish it from the natural sequence ${ }^{47}$.

Deletion of nucleotides in the middle of a claimed to be modified sequence is sufficient to distinguish it from its natural correspondent namely the removal of introns, for example, would be sufficient to provide modified structural difference. However, if the deleted nucleotide is at the end of the sequence, the modification is not sufficient, since the resulting sequence would be identical to the natural sequence.

The BPTO further believes that various substitutions of nucleotides in a given sequence may not result in any change in the protein encoded thereby, due to the degeneracy of the genetic code. Therefore, when analyzing the patenting of a sequence, one must assess whether there is an inventive step in modifying (either insertion, deletion or substitution), taking into account the fact that some groups of amino acids have common properties. Thus, the inventive requirement depends on demonstrating an unexpected effect generated by the change in the state of the art.

As for the cDNA, in particular, the Guide addresses to it in item 6.3.6. We note that, according to the same guide, one should give the

47 This is because the recombinant or recombined product may be a mere reproduction of what is already found in nature, being only manufactured in a diferent way rather than the conventional one, by means of an insertion in a host. Or it may be a true product of the recombination. 
ESTs the same type of treatment given to the cDNA. In the case of cDNA derived from messenger RNA (mRNA), normally, it is going to be different from the product of nature, as the sequence will present only the exons. Thus, in these cases it can not be considered that the cDNA molecule is equal to a natural molecule, and their patentability should be evaluated based on the requirements of novelty, inventive step and industrial application. On the other hand, when cDNA molecules are derived from mRNAs that lack introns naturally, obviously, the cDNA constitution will be equal to said strand DNA/gene served as a template for the synthesis of the mRNA. Thus, in these cases, the cDNA is not considered an invention, on the basis of Art. 10 (IX) of the LPI. In the cases of cDNA obtained from other types of RNA (such as tRNA, rRNA, etc.), they must be checked whether they are identical to natural DNA, a situation in which they would not be considered an invention.

In other words, it is exactly the understanding outlined in the US Supreme Court's decision in the Myriad Case and can serve as a parameter to the BPTO's understandings, not bumping into any legislative obstacles, as verified. Thus, the understandings outlined in the Myriad Case take relevance as they contribute to the elucidation of the framework of genetic materials, assisting the BPTO in building its understanding within the legal parameters of interpretation under which it may act.

\section{Conclusion}

This study aimed to sketch the complexity of whether or not to patent some genetic material. Thus, the objectives were: (i) to analyze the Myriad Case, exposing the final decision of the US Supreme Court; (ii) to identify if such decision was correct; and (iii) to analyze if the Brazilian Intellectual Property Law grants protection to gene sequences, demonstrating the impact of the decision in the Myriad Case.

To achieve these goals, the focus was on the analysis of the Myriad Case, in which there was the emblematic decision of the US Supreme Court for not recognizing the possibility of patenting isolated genetic sequences. Therefore, the decision was important to set parameters for distinguishing between a discovery and an invention, specifically with regard to genetic sequences.

In general, the invention is a technical solution to a technical problem, to be the creation of something hitherto non-existent; finding, moreover, is somewhat simpler than the existing disclosure. It is only justified the monopoly of intellectual property, restricting the free competition, when it is necessary to grant protection to inventions, in view of the social function that such granted intellectual property protection must fulfill (promoting scientific and technological development). 
When patenting genetic sequences, it is clear that what is at stake, in fact, is the genetic information necessary for conducting research and promoting scientific development, since they are often basic tools for science.

That is, the patentability analysis under the Brazilian legal text must go through an analysis of the legislative policy interests, pondering: the need to ensure the return of investments; the need to protect biodiversity and heritage of a nation; and the need to encourage the development of research for promotion of scientific and technological development, among others.

From the moment the desire to patent these materials is identified as a competitive tool, one should consider whether this is a viable possibility, according to the Brazilian intellectual property legal system. The starting point for such an analysis was the Myriad Case.

In the Myriad Case it was established that the isolated gene sequence was a mere discovery: the identification of the function of a single gene would be just the revelation of something already found in nature, containing information that should serve to common human knowledge. On the other hand, the US Supreme Court stated that the cDNA is patentable matter, since it is not found in nature in that way, once the natural DNA strands contains the introns and exons and the cDNA contains only exons.

We point out that the decision was correct in the sense of removing the protection for isolated DNA sequence, according to American law, but that, technically, the same grounds used to remove protection for the isolated sequence can be used with regard to the cDNA. Clearly, in both cases there is a structural difference from the product found in nature, but for the isolated sequence, the US Supreme Court has not recognized the functional difference. Likewise, the cDNA is complementary to the mRNA (which is not subject to patent), therefore there is no substantial functional difference between those fragments.

This was the prevailing understanding, although technically incorrect.

Thus, in summary:

(i) The product must be truly an invention and not a mere discovery;

(ii) A product identical to the existing product, even if derived from a new source, does not meet the novelty requirement;

(iii) A merely extracted product may not be patented;

(iv) An isolated product should be much more useful than its natural form;

(v) The product will only be considered an invention if present structural and functional differences in relation to a product of natural occurrence;

(vi) The characterization of the functional difference may stem from a significantly higher utility (greater) (new therapeutic and 
commercial value).

According to the LPI, to be patentable, an invention must meet the requirements of novelty, inventive step and industrial application (Art. 8). Established that, despite the controversy, we understood that the right of inventors, regardless of its legal nature, is a fundamental right with constitutional protection (Art. 5, XXIX, of the Brazilian Constitution). Thus, the interpretation of what is to be an invention must be broad and any restriction on this right must be strictly interpreted. Therefore, Art. 10, of the LPI is to be interpreted in the strictest possible way since it limits a fundamental right.

It is possible to restrict a fundamental righ - that is, in principle; there is no unconstitutionality in it. However, such restrictions should consider the principles at stake, namely: the free market and free enterprise, the right to intellectual property and scientific and technological development. A restriction to the fundamental right must be necessary, appropriate and proportionate to the objective to be accomplished, taking always in account the possibility of making use of compulsory licensing in the case of patent law abuse.

The BPTO, because it is a public administration office, must act guided by the principle of legality, so it can only act in strict legal terms - that is, it can grant or deny a patent based on strict legal terms.

In this sense, item IX of Art. 10 of the LPI, which deals specifically with the biological materials found in nature, including the genome, considers such products as not being an invention, with voices in the doctrine stating that, in fact, the law only excludes from patenting products that would be considered inventions - that is, the item would be best placed in Art. 18, of the LPI.

Continuing, from a more detailed analysis of the term "found in nature", we find item IX of Art. 10, of the LPI to not be technicaly correct, not even if placed in Art. 18, because it should not exist at all, since "found in nature, although isolated" would signify a mere discovery, which is already encompassed in item I of Art. 10. In other words, the item is unnecessary.

In reference to genetic materials, purely isolated sequences would be simple discoveries, since there is no functional difference from the product of nature.

With regard to the cDNA, the US Supreme Court understood to exist a functional difference. We understand that, although not found in nature in this way, the cDNA simply carries the same information contained in the gene. Similarly to the isolation, cDNA encompasses information that nature has produced, being complementary to the mRNA from which it derived.

The cDNA is the real working tool for genetic engineering (and not the merely isolated sequence), since it is more stable than the 
isolated DNA sequence itself. It is the cDNA that is contained in the basic genomic libraries for genetic engineering techniques. Therefore, the decision is innocuous for patent titleholders of isolated genetic sequences, since it is common practice to claim the cDNA in the application also.

Because one can not patent mRNA, because of its natural occurrence, the obvious solution would be to patent the cDNA - that is, it is a true fraud to the patent system. However, as the cDNA patenting was established as possible in world practice, it should be applied such understanding in Brazil as a competitive tool, attracting investors in biotechnology to Brazil, which seek, here, to protect their rights.

What this study aimed to clarify is that the analysis of biological materials, taking as a basis the analysis of genetic material, should always be in a case by case analysis and in accordance with basic principles of the intellectual property system. That is, it must be considered that only the inventions themselves deserve protection and that any patent impossibility of such inventions should find support in consideration with other fundamental rights.

Still, par excellence, products found naturally can not be considered invention, but simple discovery. We add that the differentiation between natural products and products that do not occur naturally can not just be on synthetic or isolated terms, having to present the marked difference (structural and functional). We understand also that the functional difference, as the genetic sequences, will not exist when they transmit the same genetic information as the natural sequence.

\section{REFERENCES}

ADELMAN, Martin. et al. Cases and materials on patent law. USA: American Casebook Series, 1998.

AGÊNCIA CÂMARA DE NOTÍCIAS. Abrabi reclama falta de patenteamento de moléculas puras. Brasília: [S.n.], 2005. Available at: <http://www2.camara.leg.br/camaranoticias/noticias/79407.html>. Acessed May 14, 2014.

AGITHA, T. G. Impact of IP on Public Health: the developed country scenario. Journal of Intellectual Property Rights. [S.1.], v. 18 , p. 382-389, july 2013. Available at: <http://nopr.niscair.res.in/ bitstream/123456789/20294/1/JIPR\%2018(4)\%20382-389.pdf.> Acessed May 14, 2014.

ALBERTS, B. Molecular Biology of the Cell. 5. ed. Nova Iorque: Garland Science, 2008.

AMBIENTE BRASIL. Biodiversidade: ferramenta para a 
competitividade. [S.1.: s.n., 2003]. Available at: < http://ambientes. ambientebrasil.com.br/gestao/artigos/biodiversidade $\% 3 \mathrm{~A}$ ferramenta para_a_competitividade.html.> Acessed May 14, 2014.

ANDREWS, Lori B. Patents: the need for bioethics scrutiny and legal change. Chicago-Kent Law Review, [S.1.], n. 16, fev. 2005. Available at: <scholarship.kentlaw.iit.edu/fac_schol/16>. Acessed May 09, 2014.

ASSUMPÇÃO, Eduardo. Notas sobre patentes e biotecnologia. Santa Catarina: [S.n., 20--]. Available at: http://ww.egov.ufsc.br/portal/sites/ default/files/anexos/27820-27830-1-PB.htm. Acessed May 14, 2014.

BALUCH, Andrew S. American Bar Association. USA, n.12-398, march 14, 2013. Available at: <http://www.americanbar.org/content/

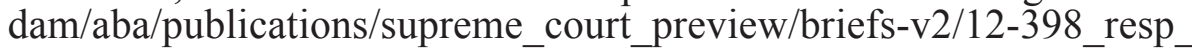
amcu_nano.authcheckdam.pdf. $>$ Acessed May 09, 2014.

BARBOSA, Denis Borges. A propriedade intelectual e a teoria do market failure. [S.1.: s.n., 2002]. Available at: <www.denisbarbosa.addr. com/arquivos/apostilas/32.doc $>$. Acessed August 13, 2013.

- Exclusividade de Dados Sigilosos apresentados às agências regulatórias: agroquímicos. [S.1.:s.n., 2008]. Available at: <http:// www.denisbarbosa.addr.com/arquivos/200/propriedade/exclusividade dados_sigilosos.pdf $>$. Acessed August 13, 2013.

- Relatório de Análise da incorporação do conhecimento $\overline{l e v a n t a d o ~ e ~ s u a ~ p o s s i ́ v e l ~ a p l i c a c ̧ a ̃ o ~ n o ~ B r a s i l ~ C o n t r a t o ~ n . ~ 2010 / 000426 . ~}$ PROGRAMA DAS NAÇÕES UNIDAS PARA O DESENVOLVIMENTO. SERVIÇOS DE CONSULTORIA. PROJETO PNUD/BRA/06/032. BRASÍLIA. Termo de Referência n. 133963. Provided by the author, via e-mail, to cladelacerda@gmail.com, on December, 2013. Not yet published.

BARBOSA, Pedro Marcos Nunes; BARBOSA, Denis Borges. $O$ Código da Propriedade Industrial conforme os Tribunais. Provided by the author, via e-mail, to cladelacerda@gmail.com, on December, 2013. Not yet published.

BARROS, Suzana de Toledo. O princípio da proporcionalidade e o controle de constitucionalidade das leis restritivas de direitos fundamentais. 2. ed. Brasília: Brasília Jurídica, 2000.

BEAUCHAMP, Christopher. Patenting nature: a problem of history. Stanford Tecnology Law Review, Brooklyn, v. 16, n. 296, 25 set. 2012. Available at: <http://papers.ssrn.com/sol3/papers.cfm?abstract $\mathrm{id}=2152105>$. Accessed July 08, 2014. 2014.

. The pure thoughts of Judge Hand: A historical note on the patenting of nature. [S.1.: s.n., 2011]. Available at: <http://www.law. 
nyu.edu/sites/default/files/ECM_PRO_071307.pdf $>$. Accessed May 09, 2014. 2014.

BELCHER, Brian and HAWTIN, Geoffrey. A patent on life: ownership of plant and animal research. In: NAIR, Krg; KUMAR, Ashok. Intellectual Property Right. New Delhi: Allied Publishers Ltd., 2005. p. 263-298. Available at: <http://books.google.com.br/books?id= orZWiAIhAzAC\&pg=PA282\&lpg=PA282\&dq=key + dismukes $+\mathrm{c}$ hakrabarty\&source $=$ bl\&ots $=$ L 12 MsQWQup\&sig $=\mathrm{jV0KFY9EivN}$ yXowiJ37amhW4f70\&hl=pt-BR\&sa $=$ X\&ei=JjBpU8TfCYrhygG $\mathrm{m} 4 \mathrm{HgBA} \& \mathrm{ved}=0 \mathrm{CE}$ oQ $6 \mathrm{AEw} A w \# \mathrm{v}=$ one page $\& \mathrm{q}=\mathrm{key} \% 20$ dismukes\%20chakrabarty\&f=false $>$. Accessed May 06, 2014.

BENNETT, I. C.; GATTAS, M.; TEH, B.T. The Genetic Basis of Breast Cancer and its Clinical Implications. Aust. N. Z. J. Surg, [S. 1.], v. 2, n. 69, p. 95 - 105, fev. 1999.

BITTAR, Carlos Alberto. Os direitos da personalidade. São Paulo: Forense, 1989.

BLAKENEY, Michael. Plant Variety Protection, International Agricultural Research, and Exchange of Germplasm: Legal aspects of sui generis and patent regimes. In: KRATTINGER, A. et al. In Intellectual Property Management in Health and Agricultural Innovation: A Handbook of Best Practices. Oxford, UK: Mirh, 2007. p. 401-417.

BOWMAN, Andrew. Genes 101: Are human genes patentable subject matter? Rich. J. L. \& Tech. [S.1.], v. 18, n. 4, [s. d.]. Available at: <http:// jolt.richmond.edu/v18i4/article15.pdf>. Accessed April 17, 2014.

BRASIL. Decreto n. 1355, de 30 de dezembro de 1994. Promulga o Acordo sobre Aspectos dos Direitos de Propriedade Intelectual Relacionados ao Comércio (TRIPS). Available at: <http://www.inpi. gov.br/images/stories/27-trips-portugues1.pdf>. Accessed May 19, 2014.

BRINCKERHOFF, Courtenay C. Alook at the myriad gene patent claims and the USPTO memo to examiners on Myriad. Foley \& Lardner LLP, USA. [S. n.], jun. 2013. Available at: $<$ http://www.pharmapatentsblog. com/2013/06/17/a-look-at-the-myriad-gene-patent-claims $>$. Accessed July 07, 2014.

BRODY, L. C.; BIESECKER, B.B. Breast Cancer Susceptibility Genes BRCA1 and BRCA2. 1998. Medicine, [s.1.], v. 77, n. 3, p. 208226, May 1998. Available at: <http://journals.lww.com/md-journal/ Citation/1998/05000/Breast_Cancer_Susceptibility_Genes_BRCA1 and.6.aspx $>$. Accessed June 02, $201 \overline{4}$.

BYRNE, Noel. Patents for genes, other biological materials and animals. 
Panor. Braz. law - Vol 3, Nos. 3 and 4 (2015)

Tibtech/Elsevier Science Publishers Ltd, UK, v. 11, p. 409-411, 1993.

CARVALHOFILHO, José dos Santos. Manual de Direito Administrativo. 6. ed. Lumen Juris: Rio de Janeiro, 2000.

CARVALHO, Ivan Lira de. A interpretação da norma jurídica. Justiça Federal do Rio Grande do Norte: Rio Grande do Norte, [19--]. Available at: <www.jfrn.gov.br/institucional/biblioteca/docs/doutrina198.doc > . Accessed May 23, 2014.

CERQUEIRA, João da Gama. Tratado da Propriedade Industrial. Rio de Janeiro: Lumen Juris, 2010. v. 1

. Tratado da Propriedade Industrial. Rio de Janeiro: Lumen Juris, 2010. v. 2. t. 1.

CLANCY, SUZANNE. DNA Transcription. Nature: USA, 2008. Available at: $\quad<$ http://www.nature.com/scitable/topicpage/dnatranscription-426>. Accessed April 15, 2014.

CONSERVATION INTERNATIONAL DO BRASIL. Megadiversidade. [S.1.:20--]. Available at: <http://www.conservation.org.br/como/index. php?id=11>. Accessed May 13, 2014.

COOK-DEGAN, Robert. HEANEY, Christopher. Gene Patents and Licensing: Case Studies Prepared fot the Secretary's Advisory Committee on Genetics, Health and Society. USA: Nature, 2010. Available at: <http:/www.nature.com/gim/journal/v12/n1s/full/ gim2010138a.html>. Accessed April 04, 2014.

COOPER, G.M. Eukaryotic RNA Polymerases and General Transcription Factors. In:__ . The Cell: A Molecular Approach. 2nd ed. Sunderland (MA): Sinauer Associates, 2000. Available at: $<$ http:// www.ncbi.nlm.nih.gov/books/NBK9935>. Accessed April 15, 2014.

COSTA, Cíntia Reis; PARANHOS, Julia; VASCONCELLOS, Alexandre Guimarães. Brasil, India e China: o marco legal da biodiversidade e a proteção patentária no âmbito do sistema farmacêutico de inovação. [S.1.: s.n., 2013]. Available at: $<$ http://www.altec2013.org/programme pdf/655.pdf $>$. Accessed May 16, 2014.

COSTA, Moacir Lobo da. A propriedade na doutrina de Duguit. Trabalho apresentado no Curso de Doutorado da USP ao Prof. Miguel Reale, 1952. São Paulo: USP, 1952. Available at: <www.revistas.usp.br/ rfdusp/article/download/66216/68826>. Accessed May 22, 2014.

DANNEMANN, SIEMSEN, BIGLER \& IPANEMA MOREIRA. Propriedade Intelectual no Brasil. Rio de Janeiro: PVDI Design, 2000.

DEL NERO, Patrícia Aurélia. Propriedade Intelectual: A tutela jurídica da biotecnologia. São Paulo: Ed. Revista dos Tribunais, 1998. 
DI BLASI, Gabriel; MARQUES MENDES, Paulo Parente; SOERENSEN GARCIA, Mario Augusto. A Propriedade Industrial. Rio de Janeiro: Forense, 2000.

DI PIETRO, Maria Sylvia Zanella. Direito Administrativo. 12. ed. Atlas: São Paulo, 2000.

DIAFÉRIA, Adriana. Clonagem, aspectos jurídicos e bioéticos. Bauru, SP: Edipro, 1999.

. Patente de Genes Humanos e a tutela dos direitos difusos. O direito ao progresso econômico, científico e tecnológico. Rio de Janeiro: Lumen Juris, 2007.

DWORKIN, Gerald. Patenting Genes - the human genome project. In: IBC CONFERENCE, 24 ${ }^{\text {th }}$ and $25^{\text {th }}$ May, 1993, Recent developments in the protection of biotechnological inventions. Europe, USA and Japan. Golden Tulip Promenade Hotel The Hague.

ESTADOS UNIDOS DA AMÉRICA. US Courts. Merck \& Co. v. Olin Mathieson Chemical Corp. 253 F.2D 156 (4 ${ }^{\text {th }}$. Circuit 1958). Available at: $\quad<$ https://casetext.com/case/merck-amp-co-v-olin-mathiesonchemical-corporation\#.U2vrPdJDvng>. Accessed May 08, 2014.

. Circuit Court, N. D. New York. Blumenthal v. Burrell et al. 10 de outubro de 1890. Available at: <https://law.resource.org/pub/us/ case/reporter/F/0043/0043.f.0667.pdf>. Accessed May 08, 2014.

. Court of Appeals for the Federal Circuit. 51 F.3D 1552 (1995). Available at: $<$ http://www.lawschoolcasebriefs.net/2013/11/in-redeuel-case-brief.html $>$. Accessed May 12, 2014.

. Court of Appeals for the Federal Circuit. Association for Molecular Pathology et all v. USPTO et al. Case n. 09-CV-4515, decidido em 16 de agosto de 2012. Available at: <http://www.cafc. uscourts.gov/images/stories/opinions-orders/10-1406.pdf $>$. Accessed April 17, 2014.

. US Courts. Parke-Davis \& Co. v H. K. Mulford Co. CCSDNY 189 F 95; 1911 U.S. App LEXIS 5245. Available at: <http://www. pubpat.org/assets/files/brca/mats/Parke-Davis, $\% 20189 \% 20 \mathrm{Fed} \% 20$ 95\%20(1911).pdf>. Accessed May 08, 2014.

. US Courts. 90 U.S. 566 (1874). Available at: <https://bulk. resource.org/courts.gov/c/US/90/90.US.566.html>. Accessed May 07, 2014.

. US Courts. Cochrane v. Badische Anilin \& Soda Fabrik, 111 U.S. 293 (1884). Available at: < http://supreme.justia.com/cases/federal/ 
us/111/293/>. Accessed May 07, 2014.

. US Courts. Diamond v. Chakrabarty, 447 (US) 303 (1980). Available at: <http://supreme.justia.com/cases/federal/us/447/303/case. html\#310>. Accessed May 06, 2014.

. US Courts. General Electric Co. v. De Forest Radio Co. 28 F. 2D 641 (3D CIR. 1928). Available at: <https://casetext.com/case/ general-electric-co-v-de-forest-radio-co-3\#.U2vnn9JDvng $>$. Accessed May 08, 2014.

.USCourts. UnderstandingtheFederalCourts. Availableat: $<$ http:// www.uscourts.gov/FederalCourts/UnderstandingtheFederalCourts/ Jurisdiction.aspx $>$. Accessed May 05, 2014.

. Supreme Court of the Unites States. Funk Brothers Seed Co. v. Kalo Inoculant Co. 333 U.S. 127 (1948). Available at: <http://supreme. justia.com/cases/federal/us/333/127>. Accessed May 08, 2014.

FAPESP (Brasil). Programa Genoma.[S.1.: 2008]. Available at: $<$ http:// www.bv.fapesp.br/pt/24/genoma-programa-vigente-de-1997-a-2008>. Accessed July 04, 2014.

FERNANDES, Márcia Santana. Uma abordagem jurídica e bioética sobre as patentes relacionadas às células-tronco humanas. Porto Alegre: [s.n.], 2008.

FIANI, Ronaldo. A tendência à harmonização internacional da proteção de patentes e seus problemas. Revista de Economia Política vol. 29, n. 3 (115), pp. 173-190, julho/setembro 2009. Available at: <http://www. scielo.br/pdf/rep/v29n3/a10v29n3.pdf >. Accessed June 18, 2014.

FRAGA, Ivana de Oliveira. Violação a identidade, intimidade, ineditismo genético, como afronta aos direitos da personalidade do indivíduo. Publiched in "Anais do XVIII Congresso Nacional do CONPEDI", that took place in São Paulo - SP, from November 04-07, 2009. São Paulo: CONPEDI, 2009. Available at: $<$ http://www.publicadireito.com. $\mathrm{br} /$ conpedi/manaus/arquivos/Anais/sao_paulo/2480.pdf $>$. Accessed September 15, 2014.

FRANÇA, Rubens Limongi. Manual de Direito Civil. $3^{\mathrm{a}}$ ed. Revista dos Tribunais: São Paulo, 1975.

FREITAS, Rogério Edivaldo; BIANCHI, Carlos. Propriedade Intelectual e aspectos regulatórios em biotecnologia: União Europeia. In Propriedade Intelectual e Aspectos Regulatórios em Biotecnologia. FREITAS e ZUCOLOTO (org.) Rio de Janeiro: IPEA, 2013.

FREITAS, Rogério Edivaldo; ZUCOLOTO, Graziela Ferrero. 
Propriedade Intelectual e aspectos regulatórios em biotecnologia: Estados Unidos. In Propriedade Intelectual e Aspectos Regulatórios em Biotecnologia. FREITAS e ZUCOLOTO (org.) Rio de Janeiro: IPEA, 2013.

GAMA JUNIOR, Lauro; BINENBOJM, Gustavo. $O$ direito à proteção patentária como direito fundamental: interpretações sistemática, teleológica, constitucional e internacional. [S.1.: Mundo Jurídico, 2004]. Vailable at: <www.mundojuridico.adv.br/cgi-bin/upload/texto820.rtf>. Accessed May 23, 2014.

GANDRA, Alana. Agência Brasil. Biotecnologia é área em que Brasil precisa investir mais recursos em inovação. [S.1.: Agência Brasil, 14 de maio de 2013]. Available at: <http://memoria.ebc.com.br/agenciabrasil/ noticia/2013-05-14/biotecnologia-e-area-em-que-brasil-precisainvestir-mais-recursos-em-inovacao>. Accessed March 17, 2014.

GOLDIM, José Roberto; FERNANDES, Márcia Santana. Caso: As patentes dos genes BRCA1 e BRCA 2. Rio Grande do Sul: UFRGS, 2013. Available at: <http://www.ufrgs.br/bioetica/brcale2.html $>$. Accessed March 17, 2014.

GOMES, Celeste Leite dos Santos Pereira; Sordi, Sandra. Aspectos Atuais do Projeto Genoma Humano. In SANTOS, Maria Celeste Cordeiro Leite (org.). Biodireito - Ciência da vida, os novos desafios. Revista dos Tribunais: São Paulo, 2001.

GOMES, Orlando. Direitos Reais. 11 ${ }^{\mathrm{a}}$ ed. Forense: Rio de Janeiro, 1995. GRAU-KUNTZ, Karin. Direito de patentes: sobre a interpretação do art. 5\%, XXIX, da Constituição Brasileira. [S.1.: s.n., 20--]. Available at: <http://www.newmarc.com.br/ibpi/d_pat.html>. Accessed May 23, 2014.

HARNESS, Jon. Myriad Misunderstandings on Parke-Davis v. Mulford. [S.1.: s.n., 2012]. Available at: <http://patentlyo.com/patent/2012/05/ myriad-parke-davis.html>. Accessed May 07, 2014.

HOEDEMAEKKERS, R. Human Gene patentes: core issues in a multilayered debate. In: Medicine, Health Care and Philosophy, v. 4, p. 218. USA: 2001.

INPI (Brasil). Diretrizes de Exame de Pedidos de Patente na Área Biotenológica (sujeita a Consulta Pública). Available at: $<\mathrm{http}$ :// www.inpi.gov.br/images/docs/diretriz_biotecnologia_consulta_ publica_30_11_12_original_0.pdf >.Accessed May 27, $201 \overline{4}$.

. Diretrizes para procedimentos de exame de patentes. Available at: <http://www.inpi.gov.br/images/stories/Procedimentos_de_Exame. pdf $>$. Accessed May 09, 2014. 
. Estudo Comparativo dos Critérios de Patenteabilidade para

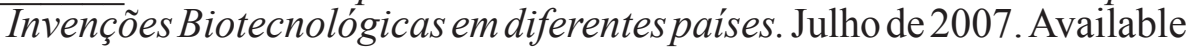
at: $\quad<\mathrm{http}$ ://www.inpi.gov.br/images/stories/Estudo_Comparativo_ dos_Critriosde_Petenteabilidadepara_Invenes_Biotecnolgicas_em_ Diferentes_Pases1.pdf.> Accessed July 04, 2014.

. Resolução 81/2013, de 28 de março de 2013. Dispõe sobre os procedimentos para a apresentação de "Listagem de Sequências", em meio eletrônico. Available at: <http://www.inpi.gov.br/images/docs/ resolucao_81-2013__listagem_de_sequencias.pdf $>$. Accessed May 27, 2014.

. Resolução den. 229/09. Dispõe sobre as regras para apresentação e representação de sequências de aminoácidos e nucleotídeos na listagem de sequências no formato OMPI ST.25. Available at: $<$ http://www.inpi. gov.br/images/stories/Resoluo_228-09-ANEXO.pdf>. Accessed May 29, 2014.

. Tabela de patentes por campos. 2012. Available at: $<$ http:// www.inpi.gov.br/images/docs/dirpa_estat_portal_out_13_tabela_4_ campo_tec_concess.pdf $>$. Accessed March 14, $201 \overline{4}$.

INSTITUTO OSWALDO CRUZ (Brasil). Patentes. Available at: $<$ http://www.fiocruz.br/ioc/cgi/cgilua.exe/sys/start.htm?sid=11 $>$. Accessed May 16, 2014.

JOLIE, Angelina. My medical choice. New York Times. New York: May 14, 2013. Available at: <http://www.nytimes.com/2013/05/14/opinion/ my-medical-choice.html?_r=0>. Accessed March 14, 2014.

KANT, Immanuel. Fundamentação da metafísica dos costumes e outros escritos. São Paulo: Ed. Martin Claret, 2011.

KELLY, Robert L. Protecting Plants under the United States Plant Patent Act. In Patent World. Inglaterra: May, 1994. pp. 26-30.

KHAN, Fazal; e KESSLER, Lindsay. Genomics Unbound: The scientific and legal case against patents based on naturally occurring DNA sequences. Nevada Law Journal vol. 13:668. USA: June, 2013. Available at: <http://digitalcommons.law.uga.edu/cgi/viewcontent. cgi? article=1918\&context=fac_artchop $>$. Accessed April 24, 2014.

KHAN, Fazal; e KESSLER, Lindsay. Gene patents no more? Deciphering the meaning of Prometheus. Annals Health L. Informed Consent 19 (2012). USA: 2012. Available at: <http://digitalcommons. law.uga.edu/fac_artchop/920>. Accessed April 24, 2014.

LEITE, Rita de Cássia Curvo. Direitos da personalidade. In Santos, 
Maria Celeste Cordeiro Leite (org.). Biodireito - Ciência da vida, os novos desafios. Revista dos Tribunais: São Paulo, 2001.

LONEY, Michael. IP practitioners "horrified" by USPTO guidelines on Myriad. In Managing Intellectual Property. USA: [s.n., March 27, 2014]. Available at: < http://www.managingip.com/TopicListArticle/3324060/ Patents-Topics/IP-practitioners-horrified-by-USPTO-guidelines-onMyriad.html?TopicListId=503>. Accessed April 09, 2014.

LOURENÇO, Juliano Javert. Caracterização de Mutações no Gene BRCA1 em Pacientes com Câncer de Mama elou Ovário Hereditários do Instituto Nacional de Câncer - RJ. Rio de Janeiro: UFRJ, May, 2003. Available at: <http://www.inca.gov.br/rbc/n_50/v01/pdf/RESUMO2. pdf $>$. Accessed October 09, 2013.

MACHLUP, Fritz; PENROSE, Edith. The patent controversy in the nineteenth century. J. Econ. Hist. Vol. 10, n. 01. USA: May, 1950. pp-1-29. Available at: <http://c4sif.org/wp-content/uploads/2010/09/ Machlup-Penrose-The-Patent-Controversy-in-the-Nineteenth-Century1950-b.pdf $>$. Accessed May 22, 2014.

MARQUES, Marilis do Valle; e SILVA, Aline Maria da. Genômica funcional: transcriptoma. In: MIR, Luís (org.). Genômica. São Paulo, SP: Atheneu, 2004. pp. 119-132.

MASNICK, Mike. Myriad Mocks Supreme Court 's Ruling on Gene Patents; Sues new competitors doing breast cancer tests. In Techdirt, July 15, 2013. USA: 2013. Available at: $<$ https://www.techdirt.com/ articles/20130713/01171423788/myriad-mocks-supreme-courtsruling-gene-patents-sues-new-competitors-doing-breast-cancer-tests. shtml>. Accessed July 07, 2014.

MEIRELLES, Hely Lopes. Direito Administrativo Brasileiro. $26^{\mathrm{a}}$ ed. Ed. Malheiros: São Paulo, 2001.

MELlo, Celso Antônio Bandeira de. Curso de Direito Administrativo. $28^{\mathrm{a}}$ ed.Ed. Malheiros: São Paulo, 2011.

. Eficácia das normas constitucionais e direitos sociais. $1^{\mathrm{a}}$ ed. $2^{\mathrm{a}}$ tiragem. São Paulo: Malheiros ed., 2010.

MELLO, Vitor Tadeu Camarrão. A repercussão geral e o writ ofcertiorari:breve diferenciação. Revista da SJRJ n. 26. Rio de Janeiro: 2009. pp; 139 - 146. Available at: <http://www4.jfrj.jus.br/seer/index. php/revista_sjrj/article/viewFile/32/30>. Accessed March 12, 2014.

MERCHANT, Gary E. Genomics, Ethics, and Intellectual Property. In: KRATTIGER, A.; MAHONEY, RT; NELSEN, L.; et al). Intellectual Property Management in Health and Agricultural Innovation: a Handbook of best practices. 2007. MIHR: Oxford, UK, and PIPRA: 
Davis, U.S.A. pp. 29-38

MINISTÉRIO DA AGRICULTURA, PECUÁRIA E ABASTECIMENTO (Brasil). Conceitos Básicos de técnicas em biologia molecular. Brasília: Setembro de 2008. Available at: < http:// ainfo.cnptia.embrapa.br/digital/bitstream/CNPA-2009-09/22214/1/ DOC191.pdf $>$. Accessed July 6, 2014.

MINISTÉRIO DO MEIO AMBIENTE (Brasil). Biodiversidade Brasileira. Brasília: [201-]. Available at: <http://www.mma.gov.br/ biodiversidade/biodiversidade-brasileira>. Accessed May 16, 2014.

MORAES, Guilherme Braga Peña de. Direitos Fundamentais: conflitos \& soluções. $1^{\mathrm{a}}$ ed. Niterói, RJ: Frater et Labor, 2000.

MOREIRA NETO, Diogo de Figueiredo. Curso de Direito Administrativo. 14 ed. Ed. Forense: Rio de Janeiro, 2006.

MOREIRA-FILHO, Carlos Alberto. Medicina Genômica e prática clínica. In MIR, Luís (org.). Genômica. São Paulo, SP: Atheneu, 2004.

MOSES, R. E.; O'MALLEY, B.W.. DNA Transcription and Repair: a Confluence. 2012. J. Biol. Chem. 287: 23266-23270. USA: The American Society for Biochemistry and Molecular Biology, Inc., 2012. Available at: <http://www.jbc.org/content/287/28/23266.full>. Accessed June 2, 2014.

MOUFANG, Rainer. Patentability of genetic inventions in animals. IIC vol. 20. N. 6/1989. pp. 823-847.

MYSZCZUK, Ana Paula; e MEIRELLES, Jussara Maria Leal de. Patentes e genoma humano: análise a partir da dignidade da pessoa. [S.1.: CONPEDI, 20--]. Available at: http://www.conpedi.org.br/ manaus/arquivos/anais/salvador/ana_paula_myszczuk.pdf. Accessed May 19, 2014.

NAVES, Bruno Torquato de Oliveira e GOIATÁ, Sarah Rêgo. Patentes de Genes Humanos. [S.1.: Publica Direito, 2013]. Available at: <http:// www.publicadireito.com.br/artigos/? cod=6d9bffd3b6ec2641>. Accessed March 14, 2014.

NIRENBERG, M.; LEDER, P.; BERNFIELD, M.; et al. RNA code words and protein synthesis on the general nature of the nature of the RNA code. USA, Maryland: National Heart Institute, National Institutes of Health, 1965. Available at: <http://www.ncbi.nlm.nih.gov/ pmc/articles/PMC219770/pdf/pnas00161-0300.pdf $>$. Accessed April 15, 2014.

PARLAMENTO EUROPEU. Diretiva 98/44, of July 6, 1998. Dispõe sobre a proteção jurídica das invenções biotecnológicas. Available 
at: < http://www.dgpj.mj.pt/sections/leis-da-justica/pdf-internacional/ directivas/directiva-98-44-ce/downloadFile/file/DIR_1998.44. pdf?nocache $=1220369858.05>$. Accessed May 1, 2014.

PASSOS-BUENO, Maria Rita. MOREIRA, Eloísa de Sá. Ferramentas Básicas da Genética Molecular Humana. In: MIR, Luís (org.). Genômica. São Paulo, SP: Atheneu, 2004.

PATENT DOCS. Gene by Gene cries uncle, settles with Myriad Genetics. Edição de 07 de fevereiro de 2014. Available at: $<$ http://www. patentdocs.org/2014/02/gene-by-gene-cries-uncle-settles-with-myriadgenetics.html $>$. Accessed July 07, 2014.

PENTEADO, Maria Isabel de Oliveira. Patentes em biotecnologia no Brasil. [S.1.:s.n., 20--]. Available at: <http://www.comciencia.br/ reportagem/transgenicos/trans15.htm>. Accessed May 06, 2014.

PEREIRA, Cilene. Microorganismos do Brasil são patenteados nos Estados Unidos. In O GLOBO, June 05, 1994. p. 40.

PETRUCELLI, N; DALY M.B.; FELDMAN, G.L.. BRCA1 andBRCA2 Hereditary Breast and Ovarian Cancer. September 04, 1998[Updated January 20, 2011]. In: Pagon RA, Adam MP, Bird TD, et al., editors. GeneReviews $^{\mathrm{TM}}$ [Internet]. Seattle (WA): University of Washington, Seattle; 1993-2013. Available at: <http://www.ncbi.nlm.nih.gov/books/ NBK1247/>. Accessed September 10, 2013.

PINTO, José Guilherme Berman C.. O writ of certiorari. In: Revista Jurídica, Brasília, v. 9, n. 86. Aug/Sep 2007. Brasília, 2007. Available at: $\quad<\mathrm{http}: / /$ www.planalto.gov.br/ccivil_03/revista/Rev_86/artigos/ JoseGuilherme_rev86.htm>. Accessed March 12, 2014.

PORTAL DA FEDERAÇÃO DAS INDÚSTRIAS DO ESTADO DE SÃO PAULO (FIESP). E preciso mudar urgentemente a lei brasileira de acesso a recursos genéticos e repartição de benefícios, afirmam especialistas. May 08, 2013. Available at: <http://www.fiesp.com.br/ noticias/e-preciso-mudar-urgentemente-a-lei-brasileira-de-acesso-arecursos-geneticos-e-reparticao-de-beneficios-afirmam-especialistas/>. Accessed May 20, 2014.

PORTAL DA INDÚSTRIA. Atraso na legislação de patentes emperra investimentos. October 10, 2013. Available at: <http://www. portaldaindustria.com.br/cni/imprensa/2013/10/1,26547/atraso-nalegislacao-de-patentes-emperra-investimentos.html>. Accessed March 17, 2014.

PORTAL DA INDÚSTRIA. Brasil precisa investir em biotecnologia, dizem especialistas em forum da CNI. October 10, 2013. Available at: $<$ http://www.portaldaindustria.com.br/cni/imprensa/2013/10/1,26555/ 
brasil-precisa-investir-em-biotecnologia-industrial-dizemespecialistas-em-forum-da-cni.html>. Accessed March 17, 2014.

PROGRAMA ANUÁRIO MATA ATLÂNTICA. Protocolo de Nagoya. São Paulo: Portal da Reserva da Biosfera da Mata Atlântica, 2004. Available at: <http://www.rbma.org.br/anuariomataatlantica/protocolo nagoya.php $>$. Accessed May 20, 2014.

PYRAH, Alli. USPTO responds to criticism of post Myriad guidelines. In: Managing Intellectual Property. USA: March 31, 2014. Available at: <http://www.managingip.com/Article/3325569/Managing-PatentsNews/USPTO-responds-to-criticism-of-post-Myriad-guidelines.html>. Accessed April 09, 2014.

RAY, Turna. Denying Injunction against Ambry BRCA Testing, Utah Judge Unconvinced of Myriad's Legal Success. In: Pharmacogenomics Report, Baylor College of Medicine Chromosomal Microarrays. March 12, 2014. Available at: <http://www.law.uci.edu/news/in-thenews/2014/PharmacogenomicsReptr burk 031214.pdf $>$. Accessed July 07, 2014.

REVISTA ÉPOCA. É hora de rever a lei de acesso aos recursos genéticos? January 09, 2013. Available at: <http://revistaepoca.globo. com/Ciencia-e-tecnologia/noticia/2013/01/e-hora-de-rever-lei-deacesso-aos-recursos-geneticos.html>. Accessed May 20, 2014.

SACCARO JR, Nilo L. A regulamentação de acesso a recursos genéticos e repartição de benefícios: disputas dentro e fora do Brasil. Ambient. soc. vol.14 no.1 São Paulo Jan./Jun 2011. Available at: $\quad<$ http://www.scielo.br/scielo.php?script=sci_arttext\&pid=S1414753X2011000100013>. Accessed May 20, 2014.

SAHU, Pradip K.; MRKSICH, Shannon. The Hatch-Waxman Act: When Is Research Exempt from Patent Infringement? ABA-IPL Newsletter, [s.1.], v. 22, n. 4, 2004. Available at: <http://www.brinksgilson.com/ resource center/85-the-hatch-waxman-act-research-exempt-frompatent-infringement>. Accessed May 05, 2014.

SALERNO, Gabriela. Boletim Informativo n. 29, July 31, 2013, de Daniel Advogados. Available at: <http://www.daniel.adv.br/port/ electronicBulletin/n29/bulletin.html>. Accessed 12, 2014.

SANTOS, Alberto Marques dos. Regras cientificas da hermenêutica. Revista Judiciária do Paraná, Ano VI, número 2. Curitiba: Amapar, jan. 2011. Available at: <http://albertodossantos.wordpress.com/artigosjuridicos/regras-da-hermeneutica/\&gt>. Accessed May 26, 2014.

SANTOS, Laymert Garcia dos. Intervenção, Descoberta e Dignidade Humana. In: CARNEIRO, F.; EMERICK (orgs.). Limite - A ética e 
o debate jurídico sobre o acesso e uso do genoma humano. Rio de Janeiro: FIOCRUZ, 2000. Available at: $<$ http://www.dbbm.fiocruz.br/ ghente/publicacoes/limite/descoberta.htm>. Accessed May 06, 2014.

SARLET, Ingo Wolfgan. Dignidade da Pessoa Humana e Direitos Fundamentais. Porto Alegre: Livraria do Advogado: 2001.

SCHOLZE, Simone Henriqueta Cossetin. Os direitos de propriedade intelectual e a biotecnologia. Brasília: Faculdade de Direito da Universidade de Brasília, Aug, 1997. Available at: <http://seer.sct. embrapa.br/index.php/cct/article/view/8916/5036>. Accessed April 14, 2014.

SHEEHAN, Teige P. USPTO to Patent Examiners: Gunpowder "is not markedly different from a product of nature". USA: HRFM, March 27, 2014. Available at: <http://www.hrfmtoday.com/2014/03/usptoto-patent-examiners-gunpowder-is-not-markedly-different-from-aproduct-of-nature.html\#sthash\%2EAfuXxi2V\%2Edpuf $>$. Accessed April 08, 2014.

SIMPSON, Andrew John George. PARRA, Juçara de Carvalho. PEREZ, José Fernando. Projeto Genoma no Brasil. In: MIR, Luís (org.). Genômica. São Paulo, SP: Atheneu, 2004.

SÓ BIOLOGIA. DNA Recombinante. [S.1.: Só Biologia, 20--]. Available at: <http://www.sobiologia.com.br/conteudos/Biotecnologia/ recombinante.php $>$. Accessed April 25, 2014.

SOUSA, André Gervásio de. Propriedade Intelectual e aspectos regulatórios em biotecnologia: Japão. In: FREITAS e ZUCOLOTO (org.). Propriedade Intelectual e Aspectos Regulatórios em Biotecnologia. Rio de Janeiro: IPEA, 2013.

STRAUS, Joseph. The Rio Biodiversity Convention and the Intellectual Property. In: CASRIP Publication Series: Rethinking Int'l Intellectual Property, n. 06. Washington: CASRIP, 2000. pp.145-166. Available at: $<$ http://www.law.washington.edu/casrip/symposium/Number6/Straus. pdf $>$. Accessed May 16, 2014.

TÁRREGA, Maria Cristina Vidotte Blanco; e PÉREZ, Héctor Leandro Arroyo. O sistema internacional de patetes e a apropriação indébita dos elementos da biodiversidade: análise crítica das propostas de solução. [S.1.: CONPEDI, 20--]. Available at: <http://www.conpedi. org.br/manaus/arquivos/anais/manaus/propried_intelectual_maria_ cristina_tarreca_e_hector_perez.pdf $>$. Accessed May 12, 2014.

TEMIN, H. M.; MIZUTANI, S. RNA-dependent DNA polymerase in virions of Rous sarcoma virus. Nature. 1970 Jul 4;227(5253):102.

TEPEDINO, Gustavo. A garantia da propriedade no direito brasileiro. 
Work presented under the title "La garantie de la propriété dans le droit brésilien", at the "Journées Vietnamiennes da Association Henri Capitant des Amis de la Culture Juridique Française", in the city of Hanoï, from November 17-21, 2003. In: Revista da Faculdade de Direito de Campos, Ano VI, No 6 - June, 2005. pp. 101-120. Available at: $\quad<$ http://fdc.br/Arquivos/Mestrado/Revistas/Revista06/Docente/04. pdf $>$. Accessed May 26, 2014.

. Notas sobre a função social dos contratos. In: TEPEDINO, Gustavo; e FACHIN, Luiz Edson (coord.) O Direito e o Tempo: embates jurídicos e utopias contemporâneas. Rio de Janeiro: ed. Renovar, 2008.

UK IPO (Inglaterra). The patent research exception: a consultation. Inglaterra: 2008. Available at: <http://www.ipo.gov.uk/consultpatresearch.pdf>. Accessed May 05, 2014.

UNESCO. Declaração Universal do Genoma Humano e dos Direitos Humanos. [S.l.: UNESCO, 1997]. Available at: <http://www.ghente. org/doc_juridicos/dechumana.htm>. Accessed May 19, 2014.

UNIVERSIA. Por dentro do Projeto Genoma no Brasil. [S.1.: March 12, 2014]. Available at: $<$ http://noticias.universia.com.br/cienciatecnologia/noticia/2004/03/12/522023/dentro-do-projeto-genoma-nobrasil.html>. Accessed July 04, 2014.

UNIVERSIDADE DE SÃO PAULO (Brazil). CENTRO DE PESQUISA SOBRE O GENOMA HUMANO E CÉLULAS-TRONCO. Projeto Genoma Humano. São Paulo: 2011. Available at: < http://genoma.ib.usp. br/wordpress/wp-content/uploads/2011/04/Projeto-Genoma-Humano. pdf $>$. Accessed July 04, 2014.

UNIVERSIDADE FEDERAL DE MINAS GERAIS (Brazil). NÚCLEO DE ANÁLISE DE GENOMA E EXPRESÃO GÊNICA. Projeto Genoma Brasileiro. Minas Gerais: [20--]. Available at: $<\mathrm{http}: / /$ www.icb.ufmg.br/biq/nage/genoma_brasileiro.html $>$. Accessed July 04, 2014.

USPTO (USA). Decisions of the Comissioner of Patents. Ex Parte Latimer, on March 12, 1889, 46 O.G. 1638. Available at: <http:// patentlyo.com/media/docs/2012/05/1889deccommrpat 123 -ex-partelatimer.pdf $>$. Accessed May 07, 2014.

. Guia Mayo-Myriad. Available at: <http://www.uspto.gov/ patents/law/exam/myriad-mayo_guidance.pdf $>$. Accessed March 13, 2014.

. Slideshow Myriad-Mayo. Available at: <http://www.uspto. gov/patents/law/exam/myriad-mayo_slides_20140319.pdf $>$. Accessed April 08, 2014. 
$\overline{\text { VAZ E DIAS, José Carlos. Intellectual property rights protection and }}$ the inflow of foreign technology and direct foreign investment: the Brazilian case. Work submitted to the University of Kent in Canterbury for obtaining the title of Doctor in Legal Philosophy in August, 1993.

VIEIRA, Adriana Carvalho Pinto. BUAINAIN, Antônio Márcio. LIMA, Fernando de. VIEIRA JUNIOR, Pedro Abel. Proteção da Biotecnologia na Agricultura. Oral presentation to the Instituto de Economia da UNICAMP; Campinas; SP; Brasil. Available at: $<$ http://www.sober.org. br/palestra/6/884.pdf>. Accessed June 18, 2014.

WATSON, J.D.; CRICK, F.H.C. A Structure for Deoxyribose Nucleic Acid. 1953. Nature. 171. pp. 737-738.

. Genetical Implications of the structure of Deoxyribonucleic Acid. 1953. Nature. 171. pp. 964-967.

WIPO. 2013 World Intellectual Property Indicators. [S.1.: WIPO, 2013]. Available at: <http://www.wipo.int/export/sites/www/freepublications/ en/intproperty/941/wipo_pub_941_2013.pdf>. Accessed March 14, 2014.

WOODLEY, John; SMITH, Gillian. Conflicts in Ethics/patents in gene $R \& D$. In: Les Nouvelles, September, 1997. pp. 119-130.

ZIEMER, Marilyn. A primer for genetic engineering. In: Les Nouvelles, June, 1992. pp. 95-101.

ZUCOLOTO, Graziela Ferrero. Propriedade Intelectual e aspectos regulatórios em biotecnologia: China. In: Propriedade Intelectual e Aspectos Regulatórios em Biotecnologia. FREITAS e ZUCOLOTO (org.) Rio de Janeiro: IPEA, 2013. 